Published in 2014. GeoBiology. 12(2): 109-118.

\title{
Periglacial fires and trees in a continental setting of central Canada, Upper
}

\section{Pleistocene}

Nicolas Bélanger ${ }^{a, d, 1}$, Christopher Carcaillet ${ }^{b, d}$, Glenn A. Padbury ${ }^{c}$, Alexis N. Harvey-Schafer ${ }^{c}$, Ken J. C. Van Rees ${ }^{c}$

N. Bélanger and C. Carcaillet are co-first authors and contributed equally to this paper.

aUER Science et technologie, Université du Québec, 5800 rue Saint-Denis, Bureau 1105, Montréal, H2S 3L5, Canada

${ }^{\mathrm{b}}$ Paleoenvironnements and chronoecology (PALECO EPHE), École Pratique des Hautes Études, and CNRS UMR5059, Institut de Botanique, 163 rue Broussonet, F-34090 Montpellier, France

${ }^{\mathrm{c}}$ Department of Soil Science, University of Saskatchewan, 51 Campus Drive, Saskatoon, S7N 5A8

${ }^{\text {d} C e n t r e ~ d ' e ́ t u d e ~ d e ~ l a ~ f o r e ̂ t, ~ U n i v e r s i t e ́ ~ d u ~ Q u e ́ b e c ~ a ̀ ~ M o n t r e ́ a l, ~ C P ~ 8888, ~ s u c c . ~ C e n t r e-v i l l e, ~ M o n t r e ́ a l ~}$ QC, H3C 3P8, Canada

${ }^{1}$ To whom correspondence should be addressed. E-mail: belanger.nicolas@teluq.ca 


\section{ABSTRACT}

Fire is a key factor controlling global vegetation patterns and carbon cycling. It mostly occurs under warm periods during which fuel builds up with sufficient moisture, whereas such conditions stimulate fire ignition and spread. Biomass burning increased globally with warming periods since the last glacial era. Data confirming periglacial fires during glacial periods are very sparse because such climates are likely too cold to favour fires. Here, tree occurrence and fires during the upper Pleistocene glacial periods in central Canada are inferred from botanical identification and calibrated radiocarbon dates of charcoal fragments. Charcoal fragments were archived in sandy dunes of central Saskatchewan, and were dated $>50,000-26,600$ cal BP. Fragments were mostly gymnosperms. Parallels between radiocarbon dates and GISP2- $\delta^{18} \mathrm{O}$ records deciphered relationships between fire and climate. Fires occurred either hundreds to thousands of years after Dansgaard-Oeschger (DO) interstadial warming events, i.e., the time needed to build enough fuel for fire ignition and spread, or at the onset of the DO event. The chronological uncertainties result from the dated material not precisely matching the fires and from the low residual ${ }^{14} \mathrm{C}$ associated with old sample material. Dominance of high-pressure systems and low effective moisture during post-DO coolings likely triggered flammable periglacial ecosystems, while lower moisture and the relative abundance of fuel overshadowed lower temperatures for fire spread. Laurentide ice sheet (LIS) limits during DO events are difficult to assess in central Canada due to sparse radiocarbon dates. Our radiocarbon dataset constrains the extent of LIS. Central Saskatchewan was not covered by LIS throughout the Upper Pleistocene, and was not a continental desert. Instead, our results suggest long-lasting periods where fluctuations of the northern tree limits and fires after interstadials occurred persistently.

\section{KEY WORDS}

Charcoal fragments / Dansgaard-Oeschger warming events / Ice-free conditions / Radiocarbon dates /Trees 


\section{INTRODUCTION}

Fire is a key component that occurs mostly during warm periods and closely controls carbon cycling (Bowman et al., 2009) and global vegetation (Bond et al., 2005). If moisture is sufficient, warm climates stimulate fuel built-up and in turn, fire ignition and spread. Since the last glacial era, biomass burning has therefore increased globally with warming periods (Daniau et al., 2012). Periglacial climates are generally thought to be too cold to favour fires. But, there are a few reports of fire activity in modern shrubby tundra (Payette et al., 1989; Higuera et al., 2008; Hu et al., 2010; Mack et al., 2011) and in periglacial environments during glacial times (Wang et al., 2005). Overall, however, few studies (e.g. Daniau et al. 2010) have examined the response of fire to climate variability across glacial periods. Fire modelling during the LGM indicated a slightly lower biomass burning activity compared to interglacials, resulting in reduced greenhouse gas (GHG) fluxes toward the atmosphere (Thonicke et al., 2005). The model is calibrated with modern vegetation processes, but does not consider the vegetation distribution at biome edges, especially in the tundra-taiga transition. Trees might have survived within tundras or cold steppes during glacial times (Kullman, 2002; Brubaker et al., 2005). Combined with soil organic matter, these scattered trees could have offered fuel for ignition and fire spread. Periglacial fires are currently uncommon, characterized by long fire return intervals and cycles (Payette et al., 1989), but could become a large source of GHG (Mack et al., 2011; Schuur et al., 2013). Future climate could also support more fires in periglacial environments (Hu et al., 2010) because of woody plant expansion into the tundra (Sturm et al., 2001; Naito \& Cairns, 2011). Increased GHG fluxes to the atmosphere from periglacial fires could lead to a positive feedback in fire activity, especially at high latitudes where warming is amplified.

During the Last Glacial Maximum (LGM), 26,500-19,000 cal BP (Clark et al., 2009), the Laurentide and Cordillera ice sheets covered most of northern North America and eventually coalesced in the southern Canadian Rockies and, despite some uncertainties, in northern areas as well (Dyke et al., 2002). Dating of erratics that formed along the coalescence of the two ice sheets 
(i.e. Foothills Erratics Train) supports that the deposition occurred during the Late Wisconsinian, close to the LGM (Jackson et al., 1997). Late Pleistocene climatic records indicate that large temperature changes at about $100,000,41,000$ and 23,000 yrs BP were caused by orbital variation in insolation (Imbrie et al., 1984). High-resolution paleoclimatic records from the circum-North Atlantic region also indicate many abrupt climatic oscillations during Marine Isotope Stage 3 (MIS 3, ca. 59,000 to 30,000 yrs BP). The rapid and significant warming events in Greenland and the North Atlantic region [known as the Dansgaard-Oeschger (DO) warming events (Dansgaard, 1993; Hubber et al., 2006)] were initially associated with a Thermohaline Circulation (THC) moving from a weak (stadials) to a strong (interstadials) state (Broecker, 2006). Within some stadials, very large volumes of ice from the Laurentide ice sheet (LIS) surged into the Atlantic ocean, referred as the Heinrich (H) events (Heinrich, 1988; Hemming, 2004). Despite that the causes of the millennial-scale climatic oscillations during MIS 3 are not yet fully elucidated (Broecker, 2006; Clement \& Peterson, 2008), they had a definite impact on the extent and timing of ice advance or recession. Dyke et al. (2002) suggested that interstadials prior to the LGM left the southern parts of the Canadian Prairies ice-free. However, there is still considerable uncertainty in regards to the extent and timing of ice advance and recession during MIS 3 in North America due to a geographically sparse database of ${ }^{14} \mathrm{C}$ dates (Burns, 1996; Dyke et al., 2001) and the lack of studies trying to relate the ${ }^{14} \mathrm{C}$ dates to climatic records from ice cores.

The main objective of the study was to document fire disturbance of ecosystems from central Saskatchewan, Canada, using ${ }^{14} \mathrm{C}$ dating and microscope identifications of paleosoil charcoal in dunes (up to a depth of $2 \mathrm{~m}$ ) at five different locations. Based on these data, we tested the following two hypotheses: (1) the extent of recession of the southwestern LIS during glacial times in central Canada was significant enough for the development of climatic conditions that were conducive to the establishment of needleleaf trees as well as the build-up of sufficient fuels to support fires on the landscape; and (2) fires were well timed with DO warming events and ice recession episodes, 
although perhaps slightly asynchronous because of a delay necessary for tree establishment and thus, fuel build-up.

\section{MATERIALS AND METHODS}

The study area $\left(54^{\circ} 40^{\prime} 53^{\prime \prime} \mathrm{N}, 105^{\circ} 29^{\prime} 55^{\prime \prime} \mathrm{W}\right.$, coordinates for soil profile 1$)$ is located in the midboreal upland of the boreal plain ecozone, approximately $20 \mathrm{~km}$ northeast of the northern edge of Montreal Lake (Fig. 1). The area investigated was relatively small, covering about $5 \mathrm{~km}^{2}$. The topography of the area is relatively flat with occasional hummocky terrains (460-490 m asl). The climate is characterized by mean monthly temperatures ranging from $-19.7^{\circ} \mathrm{C}$ in January to $16.2^{\circ} \mathrm{C}$ in July, and mean annual precipitations of $467 \mathrm{~mm}$ (National Climate Data and Information Archive, http://www.climate.weatheroffice.gc.ca/). Approximately $30 \%$ of precipitations fall as snow, which covers the ground from November to April. The local dominant trees are jack pine (Pinus banksiana), which is largely associated with Eutric Brunisols/Cambisols (or Fluvaquentic Eutropepts) developed from very sandy and excessively drained fluvioglacial parent material with low carbon levels except for layers with charcoal. Trembling aspen (Populus tremuloides), white spruce (Picea glauca) and black spruce (Picea mariana) are also found in the area but generally are associated with finer (silt and clay bands) and/or moderately well drained glaciolacustrine parent material. The understory vegetation is typically bearberry (Arctostaphyllos uva-ursi) and reindeer lichens (Cladina sp.). There is no earthworm activity in these soils due to the relatively low $\mathrm{pH}$ and the remoteness from agriculture. Tree-ring analyses and the topsoil charcoal abundance indicate that the sampled stands regenerated after fire about 45 years ago.

Five paleosoils containing buried charcoal were investigated in the Montreal Lake area (Fig. 2). The profiles were archived in sand dunes and were undisturbed by erosion, pedoturbation by freezethaw cycles or burrowing animals, suggesting that charcoal fragments were time-stratified. Charcoal layers in paleosoil 1 were collected to a depth of $2 \mathrm{~m}$ from the bottom to the surface to avoid 
contamination of fragments falling from the upper horizons. Figure 2 provides the details of the sampling scheme for paleosoil 1. Soils in this profile were also sampled based on diagnostic horizons (i.e., E, B1, B2, BC, C). In paleosoil 2, charcoal layers were sampled to a depth of $1.4 \mathrm{~m}$, again from the bottom to the surface, using the same approach as paleosoil 1 . The shallowest layer of charcoal deposition was sampled in the other three paleosoils, which corresponds to a depth of approximately $50 \mathrm{~cm}$ for paleosoils 3 and 4 and, $80 \mathrm{~cm}$ for paleosoil 5 (see Fig. 2 for the sampling scheme of paleosoil 5).

Radiocarbon $\left({ }^{14} \mathrm{C}\right)$ measurements were carried out on charcoal fragments using Accelerator Mass Spectrometry (AMS) at the LMC14 laboratory (Saclay, France). Numerous ${ }^{14} \mathrm{C}$ dates were possible for each charcoal layer as all the layers contained several charcoal fragments of $>10 \mathrm{mg}$ sample (threshold mass for AMS dating). Thus, two ${ }^{14} \mathrm{C}$ dates on different charcoal samples were obtained for three layers of paleosoil 1, whereas one ${ }^{14} \mathrm{C}$ date per layer was done in paleosoils 2 to 5 . As a whole, $17{ }^{14} \mathrm{C}$ measurements were carried out for this study. Prior to AMS dating, charcoal fragments were cleaned under a binocular $(\times 40)$ to remove the small roots, the fungi hyphae and the mineral particles that could alter charcoal age. Further, each fragment was treated for more than $24 \mathrm{~h}$ with a solution of $\mathrm{Na}_{4} \mathrm{P}_{2} \mathrm{O}_{7}$ to extract organics adsorbed within the charcoal porosity. The solution was changed daily until no more release of coloured organics was observed, which normally takes 5 to 7 days. The ${ }^{14} \mathrm{C}$ measurements were calibrated with CALIB 6.1.0 (Stuiver \& Reimer, 1993) using the Intcal09 dataset. Also, the tool "sum probabilities" of CALIB 6.1.0 was used with all measurements to compute a cumulated probability distribution, except for samples of $>50,000{ }^{14} \mathrm{C}$ years BP (i.e. SacA16565, SacA16567 and SacA27177) because the Intcal09 calibration dataset is valid only from 0 to $46,400 \mathrm{yr}$ BP. Two sigma ranges also impinged on the end of the calibration dataset for two older dates (i.e. SacA 16562 and SacA 16566) and consequently, one sigma ranges were interpreted instead. 
Only charcoal fragments $>400 \mu \mathrm{m}$ were identified from paleosoils 2 to 5 based on anatomical structure using an incident light microscope $(\times 200, \times 500, \times 1000)$ and were compared with descriptions of wood in atlases (e.g. Jacquiot, 1955; Schweingruber, 1990) or with wood charcoal in reference collections. The two genus Larix and Picea were not distinguished due to their close anatomy (Marguerie et al., 2000), resulting in the lumped charcoal taxa Larix-Picea.

\section{RESULTS}

In total, 194 fragments could be microscopically examined. Among them, only 93 fragments could be taxonomically identified. Needleleaf gymnosperm identifications in paleosoil 2 are dominant relative to broadleaf angiosperms (Table 1). Among gymnosperms, Pinus is identified in the first three layers, whereas Juniperus is in the second layer only $(70-80 \mathrm{~cm})$. Charcoal fragments in paleosoils 3 to 5 are all gymnosperms, with most of them being Pinus and few Larix-Picea types in paleosoil 3, and being either Pinus or Abies in paleosoil 5 (Table 1). About half of charcoal fragments in paleosoil 2 and most in paleosoil 4 were not identified because of an advanced stage of degradation altering the wood charcoal surfaces, which is likely related to the activity of soil microorganisms (Nocentini et al., 2010) and to the environmental conditions of combustion that control the final oxidation rate of resistant carbon (Naisse et al., 2013). Furthermore, the mechanical breakage of charcoal fragments was also possible, in time, due to frost-thaw and plant roots. These mechanisms can reduce the size of fragments according to time, albeit they do not alter the charcoal surfaces (Carcaillet \& Talon, 1996).

Radiocarbon dates of the charcoal range from $>50,000$ to $22,330{ }^{14} \mathrm{C} \mathrm{BP}$ (Table 1), which is between $>50,000$ and 26,600 cal BP (Fig. 3). This set of ${ }^{14} \mathrm{C}$ measurements $(n=17)$ is the largest record in central Canada during the Upper Pleistocene. The cumulated probability distribution of ${ }^{14} \mathrm{C}$ dates generated by the CALIB program indicates a high fire probability between 50,000 and 42,000 
cal $\mathrm{BP}$, and a lower probability at around $36,000,33,000$ and $27,000{ }^{14} \mathrm{C} B P$, which illustrates the density of calibrated charcoal dates presented in Figure 3.

Charcoal accumulation is time-stratified in paleosoil 2 with the shallowest (youngest) depth at $22,330{ }^{14} \mathrm{C} \mathrm{BP}$ and the deepest (oldest) layer at more than $50,000{ }^{14} \mathrm{C} \mathrm{BP}$ (Table 1). Time stratification of charcoal in paleosoil 1 is less clear: ages are between 44,000 and $40,000{ }^{14} \mathrm{C} \mathrm{BP}$ in the upper 120 $\mathrm{cm},>50,000$ and $44,500{ }^{14} \mathrm{C} \mathrm{BP}$ in the lower profile $(150$ to $200 \mathrm{~cm})$, but $31,470{ }^{14} \mathrm{C} \mathrm{BP}$ at $130 \mathrm{~cm}$ (Table 1, Fig. 2). This lack of pure stratification suggests more a problem of secondary accumulation by wind than the result of bioturbation. Indeed, millimetre size charcoal fragments could have been transported by wind to a few hundred meters from their source area (Clark et al., 1998; Lynch et al., 2004; Higuera et al., 2007).

Some parallel can be made between fire dates and DO warming events (Fig. 3). In the case of $>40,000$ cal BP dates, three dates were predominantly centered between the DO13 and DO12 events but overlapped with D012. The centers of these dates are approximately 2,000 years after the onset of DO13. Three dates were distinctly centered between the DO12 and DO11 events. The centers of these dates are 2,000 to 3,000 years after the onset of DO12. Three more dates overlapped with DO11. A final date lagged the onset of DO11 by $\sim 400$ years and was more closely centered during the cooling phase between the DO11 and DO10 events. For dates $<35,000$ cal BP, fires are strongly associated with DO7, DO6, DO5 and DO3. Fire dates strongly overlap DO events except with DO3 where fire appeared to have been delayed by $\sim 1,000$ years. Despite of the uncertainties with $\sim 50,000$ cal BP dates, it is safe to suggest that fires occurred between the DO14 and DO13 events.

\section{DISCUSSION}

\section{Plant Species Identification}

In total, five gymnosperm taxa are identified in the Montreal Lake paleosoils. In central Alberta, Picea wood was also dated as MIS 3 (Burns, 1996). The presence of permafrost at ice margins 
possibly hinders the establishment and growth of vascular plants, especially woody species. Our identifications demonstrate, however, that woody plants, eventually erected trees, grew in periglacial environments of MIS 3 in central Canada. It was argued that Picea and Pinus could have dominated south of the ice margin not because of cold conditions, but rather because of low atmospheric $\mathrm{CO}_{2}$ levels which would have favored gymnosperms over angiosperms (Loehle, 2007). The very large dominance of gymnosperms from charcoal identifications near the LIS margin in Montreal Lake during MIS 3 is consistent with boreal trees prevailing in periglacial environments, close to the ice-margin and, not taking refuge only in southern US areas. Our observations converge with those from Scandinavia showing that tree species (Picea, Larix, Pinus) survived in the glaciated mountains during the LGM (Kullman, 2002) probably on nunataks (Paus et al., 2006), and that afforestation occurred at the edge of the retreating ice sheet (Carcaillet et al., 2012). Matching with these north European patterns, our finding of close-to-ice presence of trees in central Canada explains why afforestation in eastern Canada occurred immediately following ice recession without a tundra phase (Richard, 1980; Liu 1990; Genries et al., 2012).

\section{Radiocarbon Charcoal Dates and Extent and Timing of Ice Advance and Recession}

The radiocarbon dates collected in this study (Table 1) along with other dates of faunal and plant remains (Burns, 1996; Dyke et al., 2001, 2002) suggest that ice recession during the MIS 3 warming events left ice-free parts of the upper Midwest and areas of the Great Plains. The most northern indication of ice-free conditions during MIS 3 is in central Alberta (Burns, 1996; Dyke et al., 2002), whereas most other dates (Dyke et al., 2001) suggest ice-free conditions in southern Alberta, Saskatchewan and Manitoba (Fig. 1). During the LGM, the ice margins were extrapolated south of the Canadian-US boundary in northern areas of Montana and North Dakota at 18,000 cal BP, with cold steppes at the ice sheet margin (Dyke, 2005). However, during MIS 3, the margins were extrapolated further north by Dyke et al. (2002) at about 30,000 cal BP from 300 to $500 \mathrm{~km}$ northeast of the highest latitudes of radiocarbon dates (Fig. 1). If the ice margins were relatively well constrained for 
Manitoba at 30,000 cal BP, they were not westward for Alberta and Saskatchewan as only a few dates are available. Our new fire evidence in central Saskatchewan during the bulk of MIS 3 effectively constrains the best approximated margin of ice recession but removes it at least another $150 \mathrm{~km}$ to the northeast (Fig. 1). This line of maximum ice recession during MIS 3, however, is built from ${ }^{14} \mathrm{C}$ dates that encompass not only a series of DO warming events (i.e. DO14 to DO2), but also cold stadials such as the $\mathrm{H} 5$ and $\mathrm{H} 2$ cooling events and episodes of continental ice advance (Fig. 3). The line in Figure 1 is therefore an interpretation of maximum ice recession due to interstadials as a whole during MIS 3 and lower MIS 2 in central Canada and was certainly not permanent between 50,000 and $26,000 \mathrm{cal} \mathrm{BP}$.

Time-series of melt water spikes in the Gulf of Mexico, a proxy of Mississippi River discharge, provided an indirect proxy for LIS advance in the Mississippi River catchment (Tripsanas et al., 2007). Four major episodes of ice advance in the Mississippi River catchment were centered at 53,000, $45,000,37,000$ and $31,200-29,400$ cal BP (Fig. 3), all of which clearly corresponding to cold periods (stadials) according to NGRIP and GICC05 years (Svensson et al., 2008). In northern Europe, similar activity was recorded at 54,000-46,000 and 35,000-30,000 cal BP (Houmark-Nielsen, 2010). We recorded high cumulated probabilities of fires from $>50,000$ cal BP until 42,000 cal BP (Fig. 3). Our fire reconstruction therefore refutes the general idea that ice covered all of Saskatchewan during these periods. Due to the small sampling area covered in this study, however, further investigations are clearly needed in the region and elsewhere in Central Canada (Alberta, Saskatchewan and Manitoba) to ascertain how much area was covered by ice and to possibly identify new evidence of plant refugium during these glacial periods.

The LGM is suggested to have peaked at about 21,000 cal BP (Clark et al., 2009), whereas Svensson et al. (2008) suggest an onset at about 27,200 cal BP and the end at 23,500 cal BP, between DO3 and DO2. The general scheme is a large and thick sheet of ice during lower MIS 2 covering western Canada and parts of the United States, from the Rockies to Great Lakes region (Dyke, 2005). The absence of charcoal ${ }^{14} \mathrm{C}$ dates associated with the DO2 warming event $(23,340 \mathrm{cal} \mathrm{BP})$ would 
corroborate this general LGM scheme, unless the hazard of charcoal sampling and dating explains this pattern. The least dated fire is approximately 1,000 years following the DO3 event, i.e. ca. 27,000 cal BP. This is the only charcoal sample dated close to the onset of the theoretical LGM.

It is hypothesized that the cooling periods between 50,000 and 32,000 cal BP, which capture DO events from DO14 to DO5, might have been too short for the LIS to progress south of Montreal Lake. The area would therefore have been ice-free for a prolonged period, allowing for gymnosperms to produce ample fuel. Although our charcoal sample is relatively small for that time period (Table 1), there is a solid density of similar dates of boreal plant remains in Michigan (Schaetzl \& Forman, 2008) and Alberta (Dyke, 2001). While boreal trees were reported in the northwestern US during MIS 3 (Jiménez-Moreno et al., 2010), they lack for the Great Plains. We therefore believe that this 18,000 yrs period between 50,000 and 32,000 cal BP interspersed by warmer events (DO) and two cold stadials reveals sustained ice-free conditions, creating suitable conditions for tree growth and for fires in central Saskatchewan.

\section{Parallels between DO Events and Fire Dates}

The charcoal data can only be used to partially infer the response of fire to climate variability across glacial periods in central Saskatchewan because the lack of fire dates at a certain period does not mean the absence of fire disturbance during that time. Another caveat is that the fire dates (especially the older dates) have a large range of uncertainty, which makes it difficult to correlate with specific climatic events (stadials vs. interstadials). Furthermore, the inbuilt age (Gavin 2001) increased this uncertainty, based on the fact that ${ }^{14} \mathrm{C}$ ages correspond to the wood age and not to the fire age (Carcaillet 1998). The problem is amplified when we consider that dead woody debris can remain centuries on the ground in periglacial areas (Payette et al., 1985) and that fires generally consume such debris (Begin \& Marguerie 2000).

The asynchronous patterns between fire and the DO warming and cooling events of MIS 3 offers too much complexity to be fully elucidate. Two general models can however be considered. 
First, our data suggest that more than half of the older fire dates (i.e. $>40,000$ cal BP), despite large sigma ranges for some dates, correspond to cooling after the DO events 14,13 and 12 (Fig. 3). This is also the case for one younger fire date (i.e. $<35,000 \mathrm{cal} \mathrm{BP}$ ) following DO3. The lagged response of fire to rapid climatic change could be explained several ways. The DO onsets have often been associated with an increase in effective moisture (Wagner et al., 2010), which would have been conducive to the establishment of vascular plants after ice removal. But fires were not likely active at that time as fuel (biomass) was still low in abundance. The abundance of fuel and low effective moisture required to dry the fuel during fire season, and thus the appropriate conditions to promote these fires, seems to have occurred in most cases only hundreds or thousands of years following the DO onsets, during stadials. These cooling periods, which are normally linked to a greater dominance of high-pressure systems and low effective moisture, were likely central to generating sufficient fuels and landscape flammability, lightning being the ignition source. At that point, lower moisture conditions and the abundance of fuels could have overshadowed the effects of lower temperatures (Higuera et al., 2008). During the last glacial episode, MIS 3 had the most variability in fires compared to MIS 2 and MIS 4, and fire increased due to DO warming events and decreased during cooling with a lag effect of ca. 100 to 200 years (Daniau et al., 2010). The much longer lag effect in central Saskatchewan could likely be explained by the need for the ice to decay completely, whereas sites collated by Daniau et al. (2010) were not at the ice margin and thus, fuels built quicker because vegetation could respond immediately to the rapid DO warming events.

Second, most younger fire dates (i.e. $<35,000$ cal BP) strongly overlap with DO events 7, 6 and 5 . There are older fire dates overlapping the DO11 onset, whereas the oldest calibrated dates also overlap with the onset of DO12 due to their large sigma ranges that likely result from a measurement bias on the oldest material poor in residual ${ }^{14} \mathrm{C}$. Because DO8, DO7, DO6 and DO5 are relatively close, it could be argued that the fire dates overlapping DO7 to DO5 events are associated with the onset of the previous DO events (e.g. DO8 vs. the fire date overlapping DO7). In such cases, the centers of these fire dates lag from 1,000 to 2,500 years the previous DO events, which would lead to similar 
conclusions as with fire dates falling within stadials. If we apply the same logic for the dates overlapping DO events 11 and 12, than the lag response of fire after DO12 is the longest at 3,5004,000 years. Such a prolonged period for fire to appear on the landscape is more of a stretch and thus, an alternative explanation is likely. Indeed, the uncertainty associated both to the ${ }^{14} \mathrm{C}$ dating and to the calibration process could result in a lag time in the chronology of events. Fire could have occurred few decades to few centuries after the age of the charcoal - cf. inbuilt age (Gavin, 2001) and burned woody debris (Begin \& Marguerie 2000). The age of charcoal would correspond to DO warming events that are wetter, thus favoring vegetation growth. Fires could have occurred either at the end of DO events or during the beginning of cold stadials. Further sampling and analysis of the charcoal in the Montreal Lake area will possibly allow to produce more robust inferences in regards to the response of fire to specific climatic events such as DO12.

\section{CONCLUSION}

We can conclude that central Canada has experienced fires during MIS 3, from >50,000 until $26,600 \mathrm{cal}$ BP. This evidence reveals fire prone environments with long lasting warm and moist periods promoting fuel built-up, notably needleleaf taxa of the boreal forest, and short dry events (season) allowing fire ignition and spread. Contrary to former glacier maps, the Montreal Lake area in central Saskatchewan was not covered by the LIS throughout the Upper Pleistocene. There is evidence that many periods were ice-free. MIS 3 in central Canada was not a periglacial continental desert, but may be a long lasting period that experienced fluctuations of the northern tree limits, where biogeochemical processes occurred under fire effects related to interstadial climate fluctuations. The ongoing tree expansion into the tundra (Sturm et al., 2001; Hallinger \& Wilmking, 2011; Naito \& Cairns, 2011) associated with the current global warming could trigger fire occurrences in periglacial areas and thus the release of GHG (Schuur et al., 2013). 
Although the causes of the millennial-scale climatic oscillations during MIS 3 are not yet fully elucidated, we provided evidence that half of the charcoal dates followed DO warming events, whereas the other half of charcoal dates preceded the following DO events. The mechanisms leading to rapid or delayed fires following the onset of DO events are thus not elucidated. If this fire evidence during these pre-DO warmings is indicative of more large-scale processes in cold treed-tundra or treed-steppe biomes, then the DO-warming could be linked to $\mathrm{GHG}$ release such as $\mathrm{N}_{2} \mathrm{O}, \mathrm{CO}_{2}, \mathrm{CH}_{4}$ that fluctuated with DO events (Flückiger et al., 2004). This biogeochemical hypothesis contributing to the DO warming onset should be investigated based on the fact that modern tundra-fires in Alaska are important processes of carbon emissions toward the atmosphere (Mack et al., 2011; Schuur et al., 2013) and, that taiga-fires situated near the tree-line was the most important contributor of carbon emissions during the Holocene in eastern Canada (Taylor et al., 1996; Bremond et al., 2010).

\section{REFERENCES}

Begin Y, Marguerie D (2000) Characterization of tree macroremains production in a recently burned conifer forest in northern Quebec, Canada. Plant Ecology 159, 143-152.

Bond WJ, Woodward Fl, Midgley GF (2005) The global distribution of ecosystems in a world without fire. New Phytologist 165(2), 525-538.

Bowman D, Balch JK, Artaxo P, Bond WJ, Carlson JM, Cochrane MA, D'Antonio CM, DeFries RS, Doyle JC, Harrison SP, Johnston FH, Keeley JE, Krawchuk MA, Kull CA, Marston JB, Moritz MA, Prentice IC, Roos Cl, Scott AC, Swetnam TW, van der Werf GR, Pyne SJ (2009) Fire in the Earth system. Science 324(5926), 481-484.

Bremond L, Carcaillet C, Favier C, Ali AA, Paitre C, Bégin Y, Bergeron Y, Richard PJH (2010) Effects of vegetation type and climatic changes on fire-induced atmospheric carbon emissions: a model based on paleodata. International Journal of Wildland Fire 19(8), 1015-1025.

Broecker WS (2006) Abrupt climate change revisited. Global Planet Change 54(3-4):211-215. 
Brubaker LD, Anderson PM, Edwards ME, Lozhkin AV (2005) Beringia as a glacial refugium for boreal trees and shrubs: new perspectives from mapped pollen data. Journal of Biogeography 32(5), 833-848.

Burns JA (1996) Vertebrate paleontology and the alleged ice-free corridor: the meat of the matter. Quaternary International 32, 107-112.

Carcaillet C (1998) A spatially precise study of fires, climate and human impact within the Maurienne valley, North French Alps. Journal of Ecology 86, 384-396.

Carcaillet C, Hörnberg G, Zackrisson O (2012) Woody vegetation, fuel and fire track the melting of the Scandinavian ice-sheet before 9500 cal yr BP. Quaternary Research 78(3), 540-548.

Carcaillet C, Talon B (1996). A view of the wood charcoal stratigraphy and dating in soil: A case study of some soils from the French Alps. Géographie Physique et Quaternaire 50(2), 233-244.

Clark JS, Lynch J, Stocks BJ, Goldammer JG (1998) Relationships between charcoal particles in air and sediments in west-central Siberia. The Holocene 8, 19-29.

Clark PU, Dyke AS, Shakun JD, Carlson AE, Clark J, Wohlfarth B, Mitrovica JX, Hostetler SW, McCabe AM (2009) The Last Glacial Maximum. Science 325(5941), 710-714.

Clement AC, Peterson LC (2008) Mechanisms of abrupt climate change of the last glacial period. Review of Geophysic 46(4), DOI: 10.1029/2006RG000204.

Daniau A-L, Harrison SP, Bartlein PJ (2010) Fire regimes during the Last Glacial. Quaternary Science Reviews 29(21-22), 2918-2930.

Daniau A-L, Bartlein PJ, Harrison SP, Prentice IC, Brewer S, Friedlingstein P, Harrison-Prentice TI, Inoue J, Izumi K, Marlon JR, Mooney S, Power MJ, Stevenson J, Tinner W, Andrič M, Atanassova J, Behling H, Black M, Blarquez O, Brown KJ, Carcaillet C, Colhoun EA, Colombaroli D, Davis BAS, D'Costa D, Dodson J, Dupont L, Eshetu Z, Gavin DG, Genries A, Haberle S, Hallett DJ, Horn SP, Hope G, Kassa TG, Katamura F, Kennedy LM, Kershaw P, Krivonogov S, Long C, Magri D, Marinova E, McKenzie GM, Moreno PI, Moss P, Neumann FH, Norström E, Paitre C, Rius D, Roberts N, Robinson GS, Sasaki N, Scott L, Takahara H, Terwilliger V, Thevenon F, Turner RB, 
Valsecchi VG, Vannière B, Walsh M, Williams N, Zhang Y (2012). Predictability of biomass burning in response to climate changes. Global Biogeochemical Cycles 26(4), GB4007, DOI: $10.1029 / 2011 \mathrm{~GB} 004249$.

Dansgaard W, Johnsen SJ, Clausen HB, Dahljensen D, Gundestrup NS, Hammer CU, Hvidberg CS, Steffensen JP, Sveinbjornsdottir AE, Jouzel J, Bond G (1993) Evidence for general instability of past climate from a 250-kyr ice-core record. Nature 364(6434), 218-220.

Dyke AS, Andrews JT, Clark PU, England JH, Miller GH, Shaw J, Veillette JJ (2001) Radiocarbon dates pertinent to defining the Last Glacial Maximum for the Laurentide and Innuitian Ice Sheets. Geological Survey of Canada, Open File 4120.

Dyke AS, Andrews JT, Clark PU, England JH, Miller GH, Shaw J, Veillette JJ (2002) The Laurentide and Innuitian ice sheets during the Last Glacial Maximum. Quaternary Science Reviews 21(13), 9-31.

Dyke AS. (2005). Late Quaternary history of Northern North America based on pollen, macrofossil, and faunal remains. Géographie Physique et Quaternaire 59(2-3), 211-262.

Flückiger J, Blunier T, Chappellaz J, Spahni R, Kawamura K, Schwander J, Stocker TF, Dahljensen D (2004) $\mathrm{N}_{2} \mathrm{O}$ and $\mathrm{CH}_{4}$ variations during the last glacial epoch: Insight into global processes. Global Biogeochemical Cycles 18(1), GB1020. 10.1029/2003GB002122

Gavin DG (2001) Estimation of inbuilt age in radiocarbon ages of soil charcoal for fire history studies. Radiocarbon 43, 27-44.

Genries A, Finsinger W, Asnong H, Bergeron Y, Carcaillet C, Garneau M, Hély C, Ali AA (2012) Local versus regional processes: can soil characteristics overcome climate and fire regimes by modifying vegetation trajectories? Journal of Quaternary Science 27(7), 745-756.

Hallinger M, Wilmking M (2011). No change without a cause - why climate change remains the most plausible reason for shrub growth dynamics in Scandinavia. New Phytologist 189, 902908. 
Heinrich $\mathrm{H}$ (1988) Origin and consequences of cyclic ice rafting in the Northeast Atlantic Ocean during the past 130,000 years. Quaternary Research 29(2), 142-152.

Hemming SR (2004) Heinrich events: Massive late Pleistocene detritus layers of the North Atlantic and their global climate imprint. Review of Geophysics 42(1), DOI:10.1029/2003RG000128.

Higuera PE, Brubaker LB, Anderson PM, Brown TA, Kenedy AT, Hu FS (2008) Frequent fires in ancient shrub tundra: Implications of paleorecords for Arctic environmental change. PLOS ONE 3(3), e1744.

Higuera PE, Peters ME, Brubaker LB, Gavin DG (2007) Understanding the origin and analysis of sediment-charcoal records with a simulation model. Quaternary Science Reviews 26, 17901809.

Houmark-Nielsen M (2010) Extent, age and dynamics of Marine Isotope Stage 3 glaciations in the southwestern Baltic Basin. Boreas 39(2), 343-359.

Hu FS, Higuera PE, Walsh JE, Chapman WL, Duffy PA, Brubaker LB, Chipman ML (2010) Tundra burning in Alaska: Linkages to climatic change and sea ice retreat. Journal of Geophysical Research 115(G4), DOI: 10.1029/2009JG001270.

Huber C, Leuenberger M, Spahni R, Fluckiger J, Schwander J, Stocker TF, Johnsen S, Landais A, Jouzel J (2006) Isotope calibrated Greenland temperature record over Marine Isotope Stage 3 and its relation to $\mathrm{CH}_{4}$. Earth and Planetary Science Letters 243(3-4), 504-519.

Imbrie J, Hays JD, Martinson DG, McIntyre A, Mix AC, Morley JJ, Pisias NG, Prell WL, Shackleton NJ (1984) The orbital theory of Pleistocene climate: support from a revised chronology of the marine $\delta^{18} \mathrm{O}$ record in Milankovitch and Climate: Understanding the response to astronomical forcing, Proceedings of the NATO Advanced Research Workshop, Editors: Berger AL, Imbrie J, Hays H, Kukla G, Saltzman B, D. Reidel Publishing, Dordrecht, pp 269-305. 
Jackson LE, Phillips FM, Shimamura K, Little EC (1997) Cosmogenic ${ }^{36} \mathrm{Cl}$ dating of the Foothills erratics train, Alberta, Canada. Geology 25(3), 195-198.

Jacquiot C (1955) Atlas d'anatomie des bois de conifères. Centre technique du bois, Paris.

Jiménez-Moreno G, Anderson RS, Desprat S, Grigg LD, Grimm EC, Heusser LE, Jacobs BF, LopezMartinez C, Whitlock CL, Willard DA (2010) Millennial-scale variability during the last glacial in vegetation records from North America. Quaternary Science Reviews 29(21-22), 2865-2881.

Lynch JA, Clark JS, Stocks BJ (2004) Charcoal production, dispersal, and deposition from the Fort Providence experimental fire: interpreting fire regimes from charcoal records in boreal forests. Canadian Journal of Forest Research 34, 1642-1656.

Kullman L (2002) Boreal tree taxa in the central Scandes during the Late-Glacial: implications for Late-Quaternary forest history. Journal of Biogeography 29(9), 1117-1124.

Liu K-B (1990) Holocene paleoecology of the boreal forest and Great Lakes-St. Lawrence forest in northern Ontario. Ecological Monograph 60(2), 179-212.

Loehle C (2007) Predicting Pleistocene climate from vegetation in North America. Climate of the Past 3(1), 109-118.

Mack MC, Bret-Harte MS, Hollingsworth RN, Jandt RR, Schuur EAG, Shaver GR, Verbyla DL (2011) Carbon loss from an unprecedented Arctic tundra wildfire. Nature 475(7357), 489-492.

Marguerie D, Bégin Y, Cournoyer L (2000) Distinction anatomique du bois du Mélèze (Larix laricina), de l'épinette blanche (Picea glauca) et de l'épinette noire (Picea mariana) en vue de I'analyse des macrorestes. Géographie Physique et Quaternaire 54, 317-325.

Naisse C, Alexis M, Plante A, Wiedner K, Glaser B, Pozzi A, Carcaillet C, Criscuoli I, Rumpel C (2013) Can biochar and hydrochar stability be assessed with chemical methods? Organic Geochemistry 60, 40-44.

Naito AT, Cairns DM (2011) Patterns and processes of global shrub expansion. Progress in Physical Geography 35(4), 423-442. 
Nocentini C, Guenet B, di Mattia E, Certini G, Bardoux G, Rumpel C (2010) Charcoal mineralization potential of microbial inocula from burned and unburned forest soil with and without substrate addition. Soil Biology and Biochemistry 42(9), 1472-1478.

Paus A, Velle G, Larsen L, Nesje A, Lie $\varnothing$ (2006) Late-glacial nunataks in central Scandinavia: biostratigraphical evidence for ice thickness from Lake Flåfattjønn, Tynset, Norway. Quaternary Science Reviews 25(11-12), 1228-1246.

Payette S, Filion L, Gauthier L, Boutin Y (1985) Secular climate change in old-growth tree-line vegetation of northern Québec. Nature 315, 135-138.

Payette S, Morneau C, Sirois L, Desponts M (1989) Recent fire history of the northern Québec biomes. Ecology 70(3), 656-673.

Richard PJH (1980) Histoire postglaciaire de la végétation au sud du lac Abitibi, Ontario et Québec. Géographie Physique et Quaternaire 34(1), 77-94.

Sanchez Goni MF, Harrison SP (2010) Millennial-scale climate variability and vegetation changes during the Last Glacial: Concepts and terminology. Quaternary Science Reviews 29, 2823-2827

Schaetzl RJ, Forman SL (2008) OSL ages on glaciofluvial sediment in northern Lower Michigan constrain expansion of the Laurentide ice sheet. Quaternary Research 70(1), 81-90.

Schuur EAG, Abbott BW, Bowden WB, Brovkin V, Camill P, Canadell JG, Chanton JP, Chapin III FS, Christensen TR, P. Ciais P, Crosby BT, Czimczik Cl, Grosse G, Harden J, Hayes DJ, Hugelius G, Jastrow JD, Jones JB, Kleinen $T$, Koven $C D$, Krinner G, Kuhry P, Lawrence DM, McGuire AD, Natali SM, O’Donnell JA, Ping CL, Riley WJ, Rinke A, Romanovsky VE, Sannel ABK, Schädel C, Schaefer K, Sky J, Subin ZM, Tarnocai C, Turetsky MR, Waldrop MP, Walter Anthony KM, Wickland KP, Wilson CJ, Zimov SA (2013) Expert assessment of vulnerability of permafrost carbon to climate change. Climatic Change 119, 359-374.

Schweingruber FH (1990) Anatomie europäischer Hölzer. P. Haupt, Bern.

Stuiver M, Reimer PJ (1993) Extended ${ }^{14} \mathrm{C}$ data base and revised CALIB $3.0{ }^{14} \mathrm{C}$ age calibration program. Radiocarbon 35(1), 215-230. 
Sturm M, Racine C, Tape KD (2001) Increasing shrub abundance in the Arctic. Nature 411, 546547.

Svensson A, Andersen KK, Bigler M, Clausen HB, Dahl-Jensen D, Davies SM, Johnsen SJ, Muscheler R, Parrenin F, Rasmussen, SO, Röthlisberger R, Seierstad I, Steffensen, JP, Vinther BM (2008) A 60000 year Greenland stratigraphic ice core chronology. Climate of the Past 4, 47-57.

Taylor KC, Mayewski TA, Twickler MS, Whitlow SI (1996) Biomass burning recorded in the GISP2 ice core: A record from eastern Canada? The Holocene 6, 1-6.

Thonicke K, Prentice IC, Hewitt C (2005) Modeling glacial-interglacial changes in global fire regimes and trace gas emissions. Global Biogeochemical Cycles 19(3), DOI: $10.1029 / 2004 G B 002278$

Tripsanas EK, Bryant WR, Slowey NC, Bouma AH, Karageorgis AP, Berti D (2007) Sedimentological history of Bryant Canyon area, northwest Gulf of Mexico, during the last 135 kyr (Marine Isotope Stages 1-6): a proxy record of Mississippi River discharge. Palaeogeography Palaeoclimatology Palaeoecology 246(1), 137-161.

Wagner JDM, Cole JE, Beck JW, Patchett PJ, Henderson GM, Barnett HR (2010) Moisture variability in the southwestern United States linked to abrupt glacial climate change. Nature Geoscience 3(2), 110-113.

Wang X, Peng PA, Ding ZL (2005) Black carbon records in Chinese Loess Plateau over the last two glacial cycles and implications for paleofires. Palaeogeography Palaeoclimatology Palaeoecology 223(1-2), 9-19. 
Table 1. Charcoal sample information, radiocarbon dates and botanical identifications of paleosoils 1 to 5 . Each radiocarbon date within a layer was measured on a distinct fragment.

\begin{tabular}{|c|c|c|c|c|c|}
\hline Paleosoil/Depth (cm) & $\begin{array}{l}\text { Laboratory } \\
\text { code }\end{array}$ & Dates $\left({ }^{14} \mathrm{C}\right.$ yr BP) & $\begin{array}{l}\text { Identified } \\
\text { charcoal (n) }\end{array}$ & Charcoal taxa $(\times n)$ & ${ }^{\ddagger}$ Sand-Silt- ${ }^{\S}$ Carbon (\%) \\
\hline \multicolumn{6}{|l|}{ Paleosoil 1} \\
\hline $48-53$ & SacA 16558 & $41,200 \pm 1,200$ & & - Not available - & $94.8-5.2-3.8$ \\
\hline $66-77$ & SacA 16559 & $39,430 \pm 940$ & & - Not available - & $84.9-15.1-5.7$ \\
\hline 66-77 (duplicate) & SacA 16560 & $43,800 \pm 1,600$ & & & idem \\
\hline $90-92$ & SacA 16561 & $39,030 \pm 890$ & & - Not available - & $88.6-11.4-3.6$ \\
\hline 90-92 (duplicate) & SacA 16562 & $44,200 \pm 1,700$ & & & idem \\
\hline $108-117$ & SacA 16563 & $41,000 \pm 1,100$ & & - Not available - & $98.7-1.3-1.4$ \\
\hline $129-131$ & SacA 16564 & $31,470 \pm 360$ & & - Not available - & $90.8-9.2-7.2$ \\
\hline $149-163$ & SacA $16565+$ & $>50,000$ & & - Not available - & $94.9-5.1-14.6$ \\
\hline 149-163 (duplicate) & SacA 16566 & $43,800 \pm 1,600$ & & & idem \\
\hline $178-183$ & SacA $16567+$ & $50,000 \pm 3,500$ & & - Not available - & $96.2-3.8-1.4$ \\
\hline \multicolumn{6}{|l|}{ Paleosoil 2} \\
\hline $50-60$ & SacA 27174 & $22,330 \pm 130$ & 30 & $\begin{array}{l}\text { gymnosperm }(\times 14) \\
\text { Pinus }(\times 5) \\
\text { angiosperm }(\times 1) \\
\text { unidentified }(\times 10)\end{array}$ & Not available \\
\hline
\end{tabular}




\begin{tabular}{|c|c|c|c|c|c|}
\hline $70-80$ & SacA 27175 & $38,250 \pm 790$ & 30 & $\begin{array}{l}\text { gymnosperm }(\times 10) \\
\text { Pinus }(\times 2) \\
\text { Juniperus }(\times 5) \\
\text { unidentified }(\times 13)\end{array}$ & Not available \\
\hline $80-100$ & SacA 27176 & $40,000 \pm 1,000$ & 30 & $\begin{array}{l}\text { gymnosperm }(\times 14) \\
\text { Pinus }(\times 2) \\
\text { unidentified }(\times 14)\end{array}$ & Not available \\
\hline $100-120$ & SacA $27177 \dagger$ & $50,100 \pm 3,300$ & 30 & $\begin{array}{l}\text { gymnosperm }(\times 5) \\
\text { unidentified }(\times 25)\end{array}$ & Not available \\
\hline \multicolumn{6}{|c|}{ Paleosoil 3} \\
\hline $50-60$ & SacA 27178 & $38,960 \pm 850$ & 24 & $\begin{array}{l}\text { gymnosperm }(\times 3) \\
\text { Pinus type banksiana }(\times 15) \\
\text { type Larix-Picea }(\times 2) \\
\text { unidentified }(\times 4)\end{array}$ & Not available \\
\hline \multicolumn{6}{|c|}{ Paleosoil 4} \\
\hline $50-60$ & SacA 27179 & $29,030 \pm 260$ & 30 & $\begin{array}{l}\text { gymnosperm }(\times 6) \\
\text { unidentified }(\times 24)\end{array}$ & Not available \\
\hline \multicolumn{6}{|c|}{ Paleosoil 5} \\
\hline $80-100$ & SacA 27173 & $28,290 \pm 260$ & 17 & $\begin{array}{l}\text { gymnosperm }(\times 11) \\
\text { Pinus }(\times 1) \\
\text { cf. Abies }(\times 2) \\
\text { unidentified }(\times 3)\end{array}$ & Not available \\
\hline
\end{tabular}

† Dates not calibrated because the Intcal09 calibration dataset is not appropriate for dates $>46,400{ }^{14} \mathrm{C}$ yr BP.

‡ samples were first treated with sodium hexametaphosphate and sonication to disperse the samples before particle size distribution measurement on the Horiba Partica LA-950 Laser Particle Size Analyzer. None of the samples contained clay.

$\S$ Sub-samples were also ground for determination of total C by dry combustion and infrared detection using the Leco CNS-2000 Analyzer. 


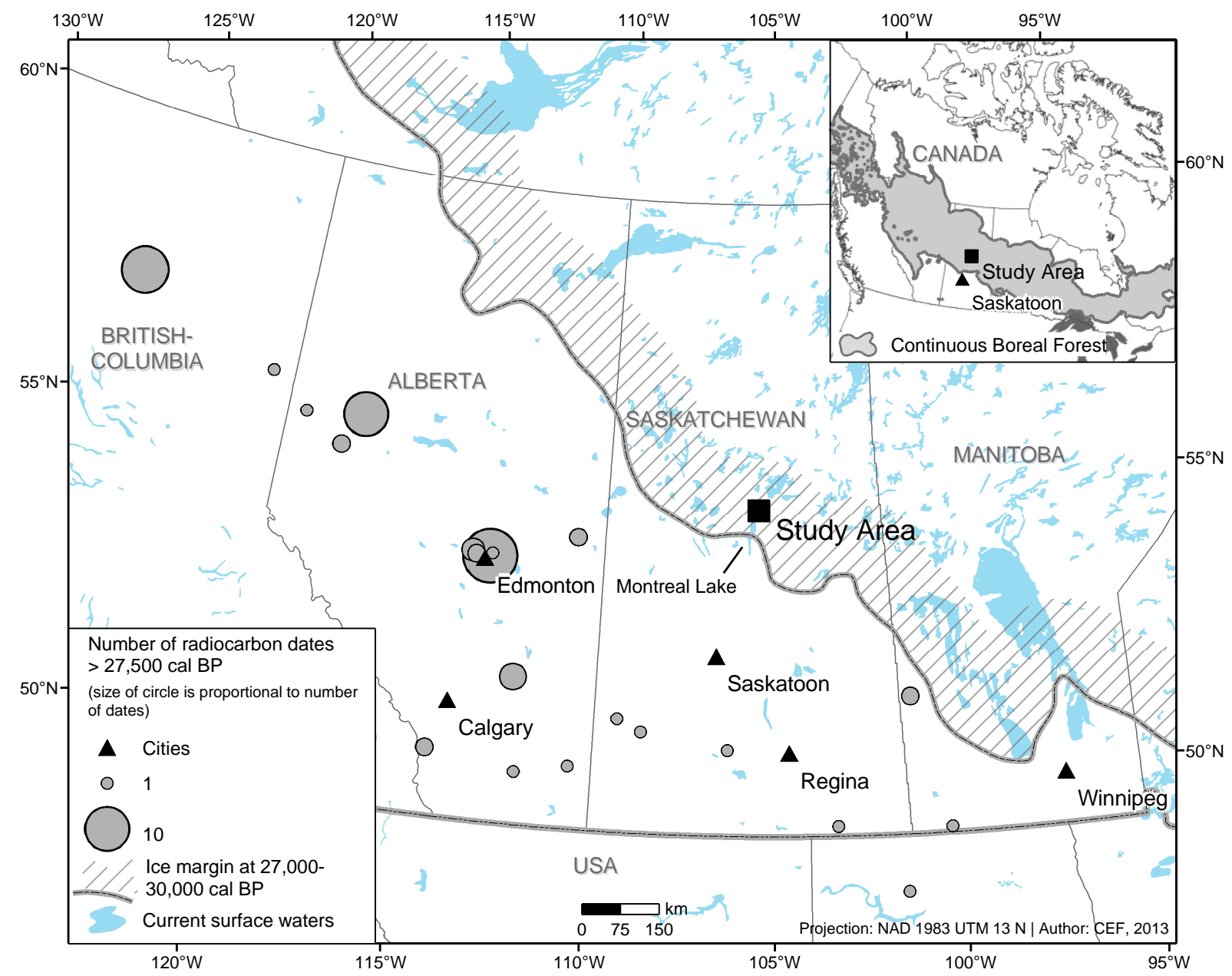

Figure 1. Location of study area and pre-Last Glacial Maximum radiocarbon dates $(50,000$ to 26,600

cal BP) collated in Central Canada, east of Rockies. The interstadial ice margin (30,000-27,000 cal BP) in the Canadian prairies (Dyke et al., 2002) is interpreted based on radiocarbon dates of faunal and plant remains (grey dots) (Burns, 1996; Dyke, 2001). The figure shows that the data from central Saskatchewan are the largest collection of ${ }^{14} \mathrm{C}$ dates during the pre-LGM (bulk of MIS 3 ) and effectively constrains the best approximated margin of ice recession but removes it another $150 \mathrm{~km}$ to the northeast (i.e. hatched area starting from the interstadial ice margin). The insert map (topright) locates the study area $\left(54^{\circ} 40^{\prime} 53^{\prime \prime} \mathrm{N}, 105^{\circ} 29^{\prime} 55^{\prime \prime} \mathrm{W}\right)$, north of Saskatoon $\left(52^{\circ} 08^{\prime} \mathrm{N}, 106^{\circ} 38^{\prime} \mathrm{W}\right)$, whereas the large grey polygon illustrates the modern extent of the boreal forest. 


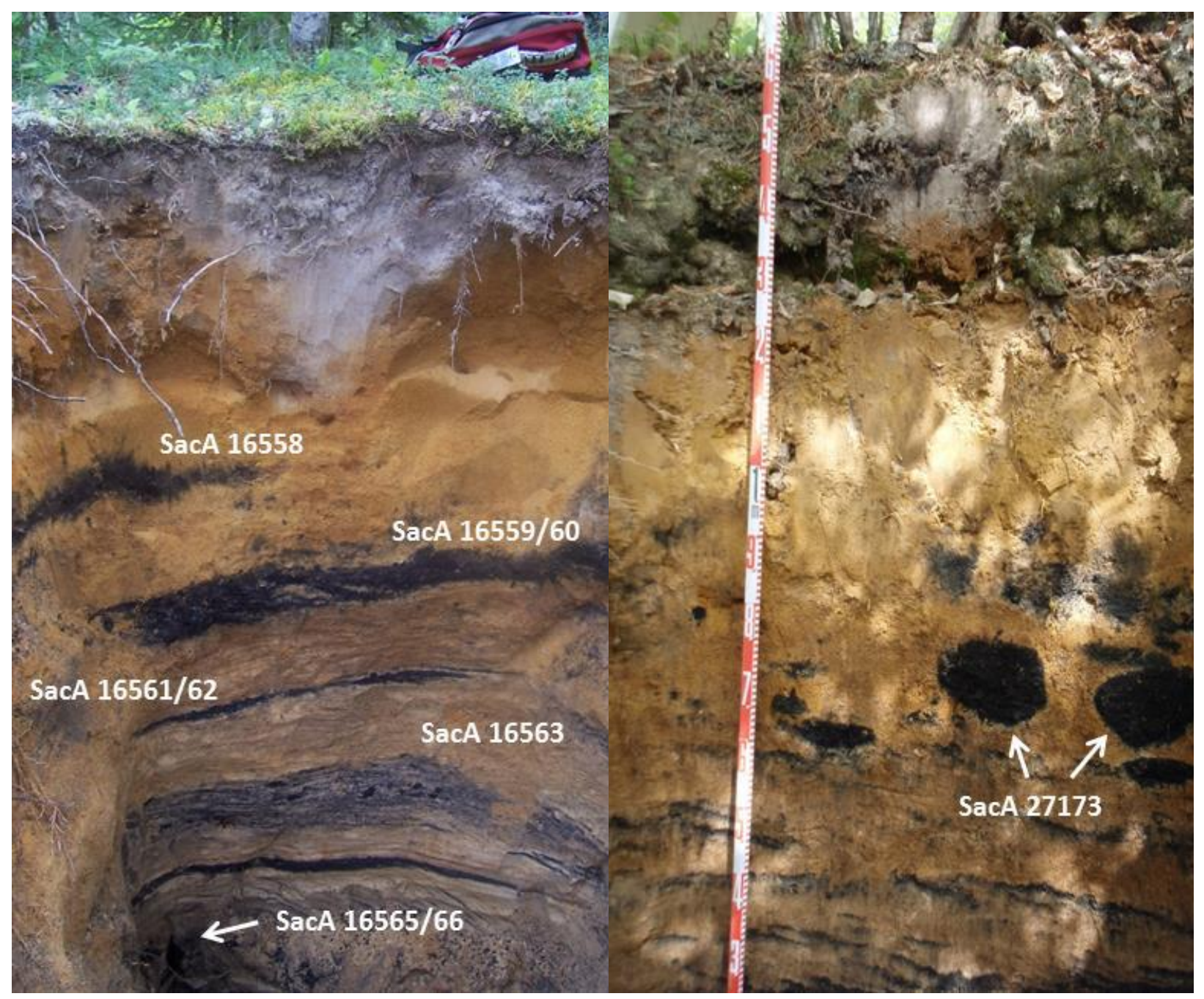

Figure 2. Charcoal depositions in paleosoils. Paleosoils 1 (left) and 5 (right) at Montreal Lake, central

Saskatchewan. Correspondence with laboratory sample codes for radiocarbon dating (Table 1) is provided, which indicates sampling intervals within the profiles. Note that sample SacA 16567 (178$183 \mathrm{~cm}$ ) in paleosoil 1 falls outside of the picture. 


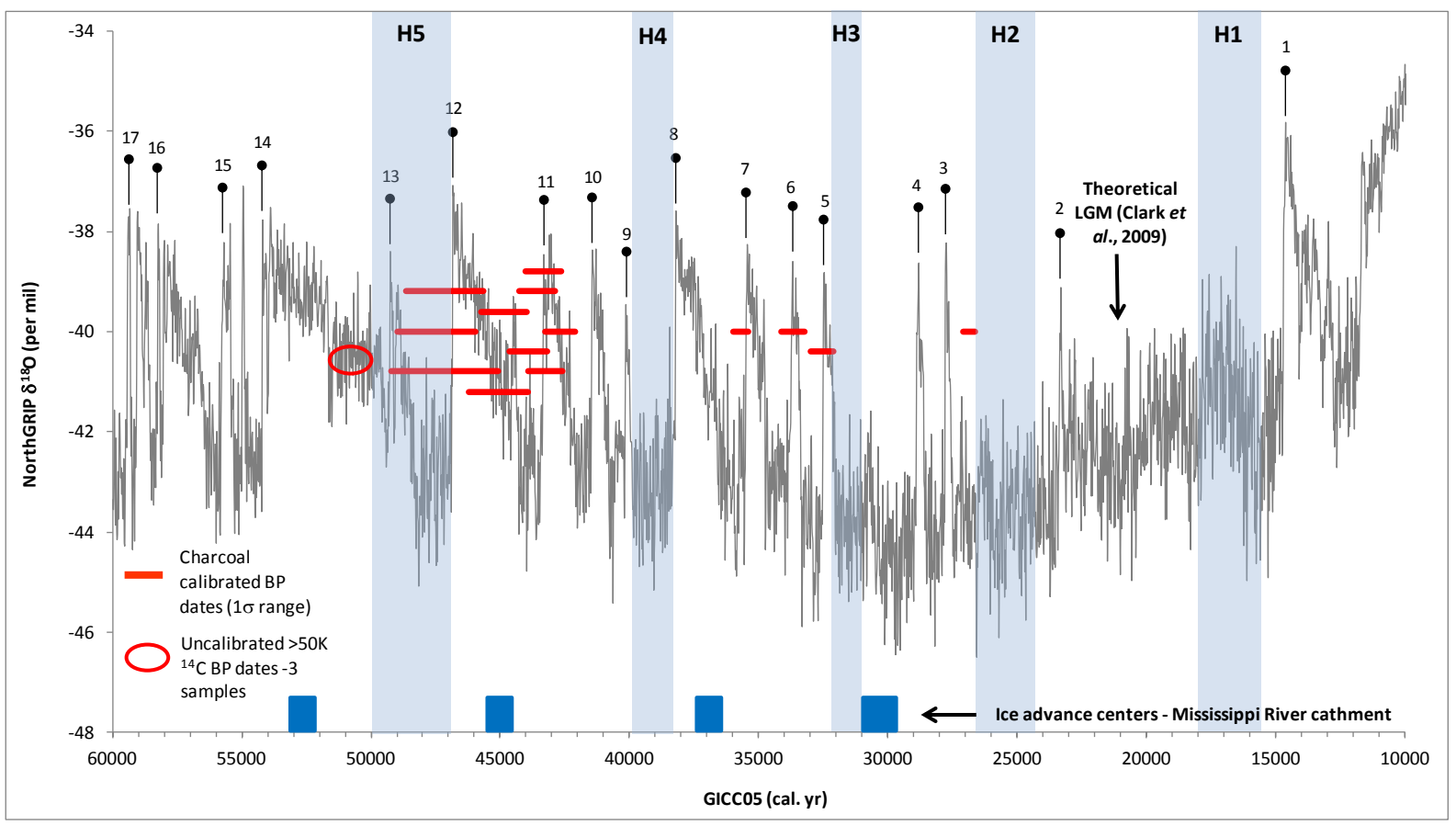

Figure 3. Comparison between NGRIP oxygen isotopes and calibrated charcoal dates from the Montreal Lake study region, central Canada, between $\sim 50,000$ and 26,600 cal BP. The fire history (red marks) is based on charcoal radiocarbon dating. Dansgaard-Oeschger (DO) events are labelled with black dots based on the most up-to-date NorthernGRIP $\delta^{18} \mathrm{O}$ climate record plotted against GICC05 calibrated years (Svensson et al., 2008). Heinrich (H) stadials 1 to 5 are labelled as vertical grey shaded areas (Sanchez Goni \& Harrison, 2010). Centres of ice advance episodes into the Mississippi River catchment, as defined by melt water spikes into the Gulf of Mexico, are labelled as blue boxes (Tripsanas et al., 2007). 